\title{
Observance of the Rights of Accused in the Conditions of Digitalization of Criminal Proceedings
}

\author{
Elena Artamonova ${ }^{1,}{ }^{*}$ Vladimir Kornukov ${ }^{2}$ Liliya Ryabova ${ }^{1}$ \\ ${ }^{1}$ North-Caucasus Federal University, Stavropol 355009, Russian Federation \\ ${ }^{2}$ Togliatti State University, Togliatti 445020, Russian Federation \\ *Corresponding author. Email: ea.artamonova@yandex.ru
}

\begin{abstract}
With the development of the information technology and its integration to criminal proceedings, the problem of ensuring the right of citizens to access justice within a reasonable time frame remains unchanged. It's especially actually for the possible introduction of the electronic form of the formation of the criminal case. It's remarkable that in such case, on the one hand, projected mobility and informativeness of the process will promote the rights and legitimate interests of the accused. On the other hand, the infringement of the rights and legitimate interests of those accused who do not possess the proper abilities and capabilities in the area of the usage of computer technologies are possible.

Keywords: Accused, rights of the accused, criminal justice, access to justice, digital technologies in criminal proceedings, electronic criminal case.
\end{abstract}

\section{INTRODUCTION}

The protection of the rights of the accused in the criminal proceeding is closely related to the ensuring the right to access justice within a reasonable time frame. The problem of the undue delays, the procrastination in the investigation and/or the legal investigation was always acute and is still acute in the criminal proceeding, especially if the accused is being held in custody. The requirements of procedural efficiency and economy are also aimed at its solution. Even before the revolution Vaskovsky called the beginning of procedural economy as the main General beginning of legal proceedings [1,89 p.]. According to it, the legal proceedings should be quick (the safety of time), simple (the work relief) and inexpensive (expenses reducing). This problem was acute even in soviet times. For example, Yakupov pointed to the necessity of "the rational conduct of legal proceedings and procedural economy" $[2,3$ p.]. In the modern criminal proceeding, the electronic registration of criminal cases can, in particular, contribute to the realization of denoted tasks [3, pp. 95-101 p.], [4, pp. 226-230], [5, pp. 57-61], [6, pp. 7-12], [7, pp. 6-12], [8, pp. 41-44], [9, 108 p.], [10].

\subsection{Literature Review}

In many foreign countries, digitalization has already become one of the directions of the future development of the criminal proceeding. For example, the criminal procedure law of the Republic of Kazakhstan provides that the criminal proceeding is conducted in paper and /or electronic formats; the person, conducting the process, can choose electronic way of forming criminal case at his discretion (art. 42.1 CPC of RK). This decision is made by a person who is charged with an investigation of the case, when it is accepted for its production [11, $72 \mathrm{p}$.]. The criminal procedure law of Estonia allows the formation of the criminal case completely or partially in the electronic-digital form in the electronic case system "e-toimik" (article 160.1 of the criminal procedure code of the Republic of Estonia) [12]. In the Federal Republic of Germany, whose criminal procedure legislation was significantly reformed in the plan under consideration in 2017 through the adoption of the law "about the introduction of the electronic form of the paperwork in criminal proceedings and further development of electronic legal relations", among other things, there are mandatory requirements, "about need of usage the electronic form of the issued and submitted documents and legal acts" [13, pp. 77-78]. So, the German law enforcement agents are obliged to make an indictment, a court order, or a Prosecutor's opinion in electronic form, and the attorneys are obliged to file complaints, private lawsuits, and final statements in such way too. Moreover, the noncompliance with the obligation without valid reason by the latest may entail bringing them to administrative responsibility [13, 78 p.].

\subsection{Methods of Assessment}

During this research, first of all, the dialectical method of scientific knowledge was used, as well as analysis and synthesis, induction and deduction, a systematic approach, questionnaires, comparative legal and formal legal methods of knowledge. Our main conclusions and suggestions are based primarily on the analysis of the valid criminal procedure legislation and its enforcement, as well as the results of the surveys, 
conducted in 2017-2019 and generalization of a judicial practice.

\subsection{Paper Structure}

The main part of this article describes the pros and cons of digitalization of Russian criminal proceedings. Specific manifestations of information technologies currently used in criminal proceedings are considered. In conclusion, the authors ' vision of the further development of Russian criminal procedure legislation on the issue under consideration is presented.

\section{RESEARCH BACKGROUND}

The introduction of digital technologies in criminal proceedings is a natural process, appeared with the help of the achievements of the information society. The Government is interested in digitalizing of the activities of all its agencies, including law enforcement. Digital technological tools contribute to the economy of the process (reduce costs) and allow increasing the effectiveness of the fight against crime. In particular, the introduction of an electronic procedure for accepting applications for crimes will solve the main problem of the initial stage of Russian criminal proceedings - concealment and untimely consideration and resolution of submitted applications for the Commission of criminal acts. The Committee of the Federation Council of the Russian Federation on constitutional legislation and state construction has already prepared a proposal to make changes to the criminal procedure law that will allow submitting statements about committed or upcoming crimes in electronic form [14].

Digital programs and new technologies that are introduced in criminal proceedings must be provided with a high degree of protection against unauthorized access to them by unauthorized persons (reliable storage of accumulated information). This is necessary, first of all, to maintain the secrecy of the investigation, to keep secret the facts of the use of security measures in relation to witnesses, victims, etc. The digital format of criminal proceedings will significantly facilitate the activities of investigative agencies and courts, as well as simplify the process of storing and searching for the criminal case materials in archives (digital files), and finally improve the quality of the work of investigative and judicial agencies. At the same time, as Golovko correctly notes, it is not possible to switch completely to the digital format for storing criminal cases. The problem of storing real material evidence remains, the significance of which in criminal proving is difficult to overestimate $[15,18 \mathrm{p}$.$] .$

Consequently, the question, which is of great practical importance, arises. How will the introduction of an electronic criminal case affect the rights of the accused?

Indeed, the mobility and speed of the process predicted by the transition to the electronic format of criminal proceedings will significantly reduce the time of investigation and consideration of criminal cases, which will certainly benefit the accused, because the time of criminal prosecution and the use of preventive measures will be reduced, which is particularly important in relation to detention. This will happen, in particular, due to more mobile and rapid interaction of professional subjects of criminal proceedings, who will be able to work quickly with the materials of the case. It will reduce the bureaucratization of the process, and vice versa, it will increase the transparency of the activities of the investigative agencies and the court will increase. Supervising (controlling) bodies will be able to exercise more complete and timely supervision (control) over the activities of investigation and inquiry agencies. At any time during the criminal proceedings, the court will be able to check the received materials immediately and make decisions on them. On the one hand, it will allow disciplining law enforcement officers and, on the other, to facilitate their work.

From the point of view of the organization of criminal procedural activities, the electronic technology of registration of criminal cases will give the access in real time to the materials of the criminal case to the participants of the process. It will allow realizing a full and timely exchange of information on the criminal case between the competent officials and agencies, and with the involved participants in the process, including the accused, which will contribute to their more effective interaction and mutual control.

At the same time, new risks of restricting the accused in the exercise of their rights appear. For example, the right to get acquainted with all the materials of the criminal case. If a criminal case is formed in electronic format, in what form will the case materials be provided to him? In electronic form or on paper? For law enforcement agencies, of course, the electronic format is preferable, as it is simpler and more economical. There are also those accused who are more comfortable, comfortable and familiar with using the electronic format, but there are other accused who, for various reasons, will categorically object to this. Such reasons include, in particular, the lack of skills in handling digital media, the lack of an appropriate material and technical base, the state of health, or the reluctance to use electronic means of communication and information transmission. What should we do? 


\section{DIGITALIZATION OF CRIMINAL PROCEEDINGS}

It seems that in the case of introduction of electronic formation of a criminal case in the Russian criminal process, it is necessary to give the accused the right to choose the optimal method of contact with the investigation agencies and the court. The accused must be given the right to receive copies of documents that must be handed over to him, as well as to submit petitions and complaints of his choice - in hard copy or in electronic form.

The accused may not be obliged to communicate exclusively in electronic form with the agencies conducting criminal proceedings. It violates his right to defense, puts him in an unequal position with the opposite side during the realization his opportunities for active participation in criminal proceedings, because not every accused person is fully equipped with digital technologies, has the ability to organize and use the electronic signature required by the criminal procedure code of the Russian Federation, has the appropriate material and technical base, etc. And as a result, it can become a significant obstacle for the accused to access justice.

The introduction of the electronic form of the criminal case, as Savchuk correctly notes, should provide a procedure that would not allow infringement or violation of the rights and legitimate interests of participants in the criminal process and, above all, the accused [16, pp. 453-454].

At the same time, even today, among the ways law enforcement officers communicate with the accused are those based on digital technologies. The law provides accused the right to file petitions and complaints to the court and request copies of judgments in the form of electronic document (article 474.1 of the code), which reduces the time of sending and receiving by the addressee of the relevant information and in that way it contributes to the accessibility and responsiveness of criminal justice.

Video conferencing is widely used for the realizing of the rights granted to the defendant. In particular, according to the literal prescriptions of the law statement of the defendant with the last word (part 1 of article 293 of the RF criminal code), participation of the accused (the defendant) in court proceedings in decision of the question of changing the territorial jurisdiction (section 6.1, article 241 UPK the Russian Federation), when considering appeals and cassation complaints and submissions (part 2 of article 389.12, part 2 of article 401.13 code of criminal procedure) is possible in this format. And even in the court of first instance for a very limited number of crimes, it is allowed to review criminal cases involving the defendant in custody by using video conferencing systems (part 6.1 of article 241 of the criminal procedure code of the Russian Federation).

This is not the end of the impact of informatization on criminal proceedings. Since July 01, 2010 [17] acts of criminal justice, with the exception of court decisions on certain categories of criminal cases, are posted on official websites of courts, which provides free access to all interested persons to the information contained in them. Since September 01, 2019, audio recording in the first and appellate courts has become necessary in criminal proceedings (part 1 of article 259 of the code of criminal procedure), which undoubtedly helps the defendants to claim the rights and legitimate interests of the accused. Moreover, new technologies find their application pointwise in specific criminal cases without any legal support. The practice is often ahead of the legislator. For example, when considering a criminal case in a court session on the charge of $A$. in the commission of a crime under part 1 of article 264 of the criminal code of the Russian Federation (violation of traffic rules that caused serious injury to a person due to negligence), according to the petition of a subsidiary defender of the defendant, confirmation of the victim's consent to the cessation of the criminal case in connection with the reconciliation of the parties was requested over the phone. A defense lawyer's usage of such an unusual technique which does not contradict the current law, helped to achieve the desired goal-the release of the defendant from criminal liability and the termination of the criminal case [18].

Everywhere in practice, rapid and modern means of communication (mobile phones, e-mail) are used to call participants of the process. Notification of participants in criminal court proceedings, including the accused, about a summons to the law enforcement officer via SMS was widely distributed. The accused, by agreeing to the SMS notification and signing the appropriate procedural form, voluntarily assumes certain obligations. This is preceded by a preliminary agreement with the accused to use this method of calling to the investigation agency, the Prosecutor or the court. This procedure is not fixed in the current code of criminal procedure of the Russian Federation, but, despite this, it is applied quite effectively in practice due to its cost-effectiveness and speed of information transfer. According to the results of a survey of judges, prosecutors, employees of investigative agencies and lawyers conducted by one of the co-authors of this study in the Komi Republic, Stavropol and Stavropol territory, Saratov, Tula, Kaluga, Tambov and Penza regions, as well as Prosecutor's offices of the southern military district Prosecutor's offices in 2017-2019, 80\% of respondents approve of the use of SMS notification in relation to the accused. $71 \%$ of them consider it possible to summon not only the defendant to court in 
this format, but also the accused (suspect) to the investigator (inquirer) and the Prosecutor [19, 53 p.]. The speed of transmission and receipt of information achieved in this way contributes to the production of the case in a reasonable time. At the same time, it is not excluded that the accused, having agreed to the SMS notification, will not fulfill the assumed obligations and will not appear on the call. Such behavior of the called person leads to negative consequences for the legal proceedings, but can the measures of criminal procedural compulsion, in particular, bringing to a court, be applied to him in such circumstances? A little more than a half of the surveyed practitioners $(53 \%)$ believe that it is possible, because there are no direct prohibitions in the law for bringing a non-appearing accused who is called by SMS notification. Only $6 \%$ of them specify that such bringing to a court is permissible if there is an agreement in the case with the accused to call him via SMS notification, and only $2.5 \%$ consider that the presence in the case of confirmation of receipt of SMS is a mandatory condition for using the bringing to a court in such cases $[19,54$ p.].

It seems that the position of practitioners above is wrong. Today, the absence of an accused person notified by TEXT message cannot be considered a legitimate reason for bringing to a court, which is explained by two points. First, it is impossible to track reliably the fact that the accused received an SMS containing information about his call. Any other method of summoning the duty to appear does not impose procedural responsibility on the accused in the form of bringing to a court, summons. In order for the procedure of consideration to work effectively and not fail, it must be clearly established in the norms of the criminal procedure law.

As a positive example of solving this issue, we can cite the regulation of the delivery of the summons by electronic means (by e-mail or via the electronic case system "e-toimik"), provided for in article 165 of the criminal procedure code of the Republic of Estonia. Estonian criminal procedure act contains detailed guidelines on what and when confirms the receipt of the summons by the addressee (a stamp on e-mail or opening or confirmation of its receipt without opening in the information system within three days from the moment of sending the summons), and how you need to act as enforcers in the absence of such confirmation (send a summons by registered letter with notification or handed in person against signature) [12].

\section{CONCLUSIONS}

The complete transition of criminal proceedings from paper to electronic criminal cases is inevitable in the future, but both in the process of transition and in the future, the accused must have the choice of the optimal method of contact with the law enforcement officer. His opinion on this issue should be taken into account as much as possible, because in the course of criminal proceedings, the fate of the accused is decided. In order to properly ensure the right to protection and access to justice, the accused should be given the right by law to choose the format of the criminal case with which it is preferable for him to work: to familiarize himself with documents, receive copies, submit complaints in the traditional way (on paper) or via electronic document management.

\section{REFERENCES}

[1] E. V. Vaskovsky, Textbook of civil procedure, Izdanie brtatyev Bashmakovykh, 1917, 429 p.

[2] R. X. Yakupov, Procedural terms in Soviet criminal proceedings (at the stages of criminal case initiation and preliminary investigation), Autoref. Dis. Cand. yurid. nauk, AMMIAR, 1972, 15 p.

[3] O. V. Kachalova, Yu. A. Tsvetkov, Electronic criminal case-a tool for modernizing criminal proceedings, Russian law-judge 2 (2015) 95-101.

[4] L. V. Bertovsky, Blockchain Technology in the criminal process as an element of digital ship production, Problems of Economics and legal practice 6 (2017) 226-230.

[5] O. I. Andreeva, O. A. Zaitsev, Prospects of conducting Russian criminal proceedings in electronic format, Criminal justice 12 (2018) 57-61. DOI: https://doi.org/10.17223/23088451/12/11

[6] I. M. Belyaeva, A. K. Kusainova, B. M. Nurgaliev, Problems of introduction of the electronic format of criminal investigation in the Republic of Kazakhstan, Bulletin of the South Ural state University 18(2) (2018) 7-12. DOI: https://doi.org/10.14529/law180201

[7] S. V. Zuev, Electronic criminal case: for and against, Law and order: history, theory, practice 4(19) (2018) 6-12.

[8] Yu. N. Posnanski, Electronic criminal case in solving the problem of investigating criminal cases in a reasonable time, Proceedings of the Academy of management of the Ministry of internal Affairs of Russia 1(33) (2015) 41-44.

[9] A. A. Sarapulov, Information technologies in criminal proceedings: history, modern state, prospects, Bulletin of the South Ural state University 13(2) (2013) 107-108. 
[10] A.M. Dolgov (2018) Electronic criminal case in the pre-trial stages of the criminal process in Russia. domhors.ru/rus/files/arhiv_zhurnala/pep/2018/9/law/dolgov. pdf Accessed 23 May 2020.

[11] V. A. Zadorozhnaya, Criminal proceedings in electronic format under the legislation of the Republic of Kazakhstan, Law and order: history, theory, practice 4(19) (2018) 70-75.

[12] The Criminal procedure code of the Republic of Estonia: law of February 12, 2003 (ed. from 07.05.2020).

https://v1.juristaitab.ee/ru/zakonodatelstvo/ugolovnoprocessualnyy-kodeks Accessed 23 May 2020.

[13] A. I. Zazulin, Normative support of electronic document management in criminal proceedings: experience of Germany, Law and order: history, theory, practice 4 (19) (2018) 76-80.

[14] RIA NOVOSTI (2020) The Council of Federation proposed to allow electronic applications to be submitted to the police. https://ria.ru/20200520/1571744505.html Accessed 23 May 2020

[15] L. V. Golovko, Digitalization in criminal proceedings: local optimization or global revolution? Bulletin of economic security 1 (2019) 15-25.

[16] T. A. Savchuk (2019) Electronic form of criminal case as an element of Informatization of investigative activity: prerequisites and problems of implementation. www.institutemvd.by/components/com_chronoforms5/ chronoforms/uploads/20160713093354_Savchuk.pdf Accessed 24 May 2020.

[17] On providing access to information on the activity of courts in the Russian Federation: fer. law of December 22, 2008 No. 262-FZ (ed. from 28.12.2017). http://www.consultant.ru/document/cons_doc_LAW_8 2839/ Accessed 24 May 2020.

[18] Resolution on exemption from criminal liability and termination of the criminal case of the Budyonnovsky city court of Stavropol Area dated March 26, 2018. Case no. 1-121/2018. https://budenovsky--

stv.sudrf.ru/modules.php?name=sud_delo\&srv_num $=1$ \&name_op=doc\&number $=52593345 \&$ delo_id $=154000$ 6\&new=\&text_number=1 Accessed 24 May 2020.

[19] E. A. Artamonova, Will of the accused in criminal proceedings, Yurlitinform, 2019, 336 p. 